\title{
GLOSY
}

PrZeELLID SEJMOWY

nr 5(160)/2020, s. 201-219; https://doi.org/10.31268/PS.2020.72

\section{Glosa do wyroku Trybunału Konstytucyjnego z 11 grudnia 2019 r., sygn. akt P 13/18}

Komentowane orzeczenie dotyczy oceny zgodności z Konstytucją RP przepisów regulujących skutki wykreślenia podmiotów wpisanych do dawnych rejestrów handlowych, które nie dopełniły obowiązku wpisania do nowego Krajowego Rejestru Sądowego. Mienie tych podmiotów przeszło na własność Skarbu Państwa, zaś prawa wspólników, członków spółdzielni i innych osób uprawnionych do udziału $\mathrm{w}$ majątku likwidacyjnym wygasły $\mathrm{z}$ chwilą wykreślenia podmiotu $\mathrm{z}$ rejestru. Trybunał nie zakwestionował samego mechanizmu uporządkowania stosunków własnościowych po podmiotach wykreślonych z rejestru, jednak uznał, że rozwiązanie tego problemu przez ustawodawcę nie było w pełni prawidłowe, nie przeszło bowiem testu proporcjonalności w odniesieniu do roszczeń względem tego mienia przysługujących byłym wspólnikom spółek czy członkom spółdzielni.

Autor zasadniczo zgadza się ze stanowiskiem Trybunału, w glosie podnosi jednak uwagi polemiczne co do pewnych argumentów przytoczonych w uzasadnieniu wyroku. Ponadto wskazuje, że warto uzupełnić argumentację Trybunału o pewne wątki, które zostały pominięte przez Trybunał z przyczyn formalnoprawnych.

SŁOWA KLUCzowe: ochrona własności, wywłaszczenie, rejestr przedsiębiorców, zasada równości, zasada proporcjonalności, odpowiedzialność odszkodowawcza za bezprawie legislacyjne, wznowienie postępowania

\section{Commentary to the Judgment of the Constitutional Tribunal of 11 December 2019, Ref. No. P 13/18}

The commented judgment concerns the assessment of the compliance with the Polish Constitution of the provisions regulating the effects of removal of the entities entered in the former commercial registers which have not been entered to the new National Court Register. The property of these entities was taken over for the benefit of the State Treasury, and the rights of partners, cooperative members and other persons to a share in the liquidation of assets expired upon the removal of the entity from the register. The Tribunal did not question the mechanism of the arrangement of the ownership relations of the entities removed from the register. Nevertheless, the Tribunal considered that the legislator's solution to this problem was not entirely correct, as it did not pass the proportionality test in respect of claims against this property of former company partners or cooperative members.

The author agrees in principle with the Tribunal's position, but in his commentary he raises polemical remarks about certain arguments cited in the justification of the judgment. In addition, the author points out that it is worth supplementing the Tribunal's argumentation with certain threads that were omitted by the Tribunal for formal and legal reasons. 
KEY WORDS: protection of property, expropriation, register of entrepreneurs, principle of equality, principle of proportionality, liability for damages for legislative unlawfulness, resumption of proceedings

Art. 9 ust. $2 b$ zdanie trzecie ustawy z dnia 20 sierpnia 1997 r. - Przepisy wprowadzajace ustawe o Krajowym Rejestrze Sądowym ${ }^{1}$ [...] jest niezgodny z art. 64 ust. 1 w zwiazku z art. 31 ust. 3 Konstytucji Rzeczypospolitej Polskiej.

Ponadto postanawia: na podstawie art. 59 ust. 1 pkt 2 ustawy z dnia 30 listopada 2016 r. o organizacji i trybie postępowania przed Trybunatem Konstytucyjnym ${ }^{2}$ [...] umorzyć postępowanie w pozostatym zakresie ${ }^{3}$.

\section{Wprowadzenie}

Komentowane orzeczenie dotyczy zagadnień interesujących zarówno w perspektywie doktrynalnej, jak i praktycznej. W aspekcie stricte naukowym orzeczenie porusza nader ważkie kwestie stosowania konstytucyjnych standardów ochrony własności i proporcjonalności w procesach normatywnego porządkowania stosunków własnościowych. Praktyczna doniosłość komentowanego orzeczenia wynika natomiast $\mathrm{z}$ faktu, że kwestionowane regulacje stały się podstawą różnego rodzaju sporów prawnych, co ciekawe, zarówno przed sądami powszechnymi, jak i sądami administracyjnymi. Zawisły przed sądem powszechnym spór dotyczący kwestii roszczeń odszkodowawczych względem Skarbu Państwa za szkody wynikłe z przejęcia mienia spółki, która utraciła byt prawny w wyniku normatywnego procesu porządkowania wpisów w rejestrach handlowych, stał się kanwą pytania prawnego skierowanego do Trybunału. Spory odszkodowawcze z udziałem Skarbu Państwa będą również konsekwencją wyroku Trybunału, na co sam Trybunał zwrócił uwagę w uzasadnieniu swojego orzeczenia. Nie jest to jednak jedyna płaszczyzna sporów prawnych. Sporny przepis był i jest podstawą wydawania decyzji administracyjnych, które były i są przedmiotem kontroli sądów administracyjnych. Potencjalny wpływ wyroku Trybunału na te spory (już prawomocnie zakończone albo zawisłe) warty jest również omówienia.

Zasadniczo zgadzam się ze stanowiskiem Trybunału, co do pewnych argumentów chciałbym jednak podnieść uwagi polemiczne. Co więcej, pewne wątki w argumentacji Trybunału zostały pominięte z przyczyn formalnoprawnych (umorzenie postępowania z uwagi na niedopuszczalność wydania orzeczenia), a zasługują na rozwinięcie w postaci komentarza doktrynalnego, jakim jest glosa.

\footnotetext{
${ }^{1}$ Dz.U. z 1997 r. nr 121, poz. 770, ze zm. [dalej: p.w.KRS].

2 Dz.U. z 2016 r. poz. 2072, ze zm.

3 Wyrok TK z 11 grudnia 2019 r., sygn. akt P 13/19, OTK-A 2019, poz. 68.
} 


\section{Przedmiot kontroli konstytucyjnej}

Powszechna dostępność komentowanego orzeczenia zwalnia mnie z konieczności szczegółowej prezentacji stanu sprawy, dlatego ograniczę się do przypomnienia tych elementów, które będą istotne w kontekście prowadzonych przeze mnie rozważań.

Postępowanie przed Trybunałem zostało zainicjowane pytaniem prawnym Sądu Okręgowego Warszawa-Praga w Warszawie. Pytanie dotyczyło art. 9 ust. 2b p.w.KRS, jednak właściwa ocena sytuacji, w jakiej powstały wątpliwości konstytucyjne, wymaga odniesienia się do całej regulacji, której ten przepis jest fragmentem. Art. 9 p.w.KRS (w brzmieniu objętym kontrolą konstytucyjności) przewidywał zachowanie mocy dotychczasowych wpisów w rejestrach sądowych, do czasu rejestracji danego przedsiębiorcy, zgodnie z przepisami nowej ustawy o Krajowym Rejestrze Sądowym, nie dłużej jednak niż do dnia 31 grudnia 2015 r. (ust. 2; termin ten był trzykrotnie przesuwany przez ustawodawcę). W tym czasie podmioty podlegające obowiązkowi wpisu do Krajowego Rejestru Sądowego zgodnie z przepisami nowej ustawy miały obowiązek złożyć wniosek o wpis do nowego rejestru. Podmioty, które podlegały obowiązkowi „przerejestrowania" i które do dnia 31 grudnia 2015 r. nie złożyły wniosku o wpis do rejestru, uznaje się za wykreślone z rejestru z dniem 1 stycznia 2016 r. (art. 9 ust. 2a p.w.KRS). Mienie tych podmiotów nabył z dniem 1 stycznia 2016 r. nieodpłatnie z mocy prawa Skarb Państwa. Skarb Państwa ponosi odpowiedzialność z nabytego mienia za zobowiązania podmiotów, które nie dopełniły obowiązku „przerejestrowania”. Prawa wspólników, członków spółdzielni i innych osób uprawnionych do udziału w majątku likwidacyjnym wygasają z chwilą wykreślenia podmiotu z rejestru (art. 9 ust. 2b p.w.KRS ${ }^{4}$ ). Nabycie przez Skarb Państwa w powyższym trybie własności nieruchomości albo użytkowania wieczystego stwierdza, w drodze decyzji, starosta właściwy ze względu na miejsce położenia nieruchomości (art. 9 ust. 2 i zd. 1 p.w.KRS).

Istotne dla dalszych rozważań jest wyjaśnienie, że sprawa, na kanwie której sąd skierował pytanie prawne, dotyczyła powództwa byłego wspólnika spółki z ograniczoną odpowiedzialnością, wykreślonej z rejestru handlowego na podstawie art. 9 ust. $2 \mathrm{~b}$ p.w.KRS, przeciwko Skarbowi Państwa, o odszkodowanie za mienie, które na podstawie spornej regulacji przeszło z mocy prawa nieodpłatnie na Skarb Państwa.

Pytający sąd, podnosząc swoje wątpliwości co do zgodności spornego przepisu z ustawą zasadniczą, wskazał na kilka wzorców konstytucyjnych: art. 21 ust. 2, art. 32, art. 64 oraz art. 77 Konstytucji RP. Merytoryczne rozstrzygnięcie Trybunału zostało dość mocno ograniczone w stosunku do zakresu pytania prawnego.

Po pierwsze, Trybunał ograniczył przedmiot kontroli merytorycznej wyłącznie do normy wyrażonej w zd. 3 art. 9 ust. 2 p.w.KRS, a zatem do normy wygaszającej prawa wspólników, członków spółdzielni i innych osób uprawnionych do udziału w majątku likwidacyjnym.

\footnotetext{
4 Przepis ust. 2b został dodany ustawą z dnia 28 listopada 2014 r. o zmianie ustawy o Krajowym Rejestrze Sądowym oraz niektórych innych ustaw, Dz.U. z 2014 r. poz. 1924.
} 
Ograniczenie przedmiotu kontroli konstytucyjnej należy uznać za w pełni uzasadnione. Przesądza o tym przesłanka funkcjonalna dopuszczalności pytania prawnego do Trybunału Konstytucyjnego, wyrażająca się w konieczności wykazania związku pytania prawnego z zawisłą przed sądem pytającym sprawą. Prawidłowe rozstrzygnięcie tej sprawy ma być uwarunkowane oceną konstytucyjności kwestionowanego przepisu.

Uzupełniając argumentację Trybunału w tym względzie, trzeba zwrócić uwagę, że w przepisie art. 9 ust. 2 b p.w.KRS są zawarte dwie normy prowadzące do pozbawienia praw majątkowych. Pierwsza została wyrażona w zdaniu pierwszym tego przepisu i odnosi się do mienia samego podmiotu, który został wykreślony z rejestru. Druga jest wyrażona w zdaniu trzecim i dotyczy przysługujących wspólnikom (członkom spółdzielni, innym uprawnionym) praw majątkowych (roszczeń) do partycypacji w majątku pozostałym po tej spółce czy spółdzielni. Skoro w rozpoznawanej sprawie chodziło o roszczenia byłego wspólnika spółki, konieczny związek funkcjonalny pomiędzy sprawą zawisłą przed sądem odsyłającym a oceną konstytucyjności istnieje tylko w odniesieniu do tej drugiej normy. Pierwsza norma rozstrzyga o bycie prawnym mienia spółki (spółdzielni), ale nie o bycie prawnym roszczeń wspólnika czy udziałowca do partycypacji w podziale składników majątkowych powstałych po podmiocie, który utracił byt prawny. Jest to zagadnienie bardzo istotne dla oceny skutków orzeczenia Trybunału, do czego powrócę w dalszej części rozważań.

Należy także odnotować, że Trybunał znacząco ograniczył wzorce kontroli. Spośród wskazanych przez sąd pytający, ostatecznie w merytorycznym rozstrzygnięciu Trybunał odniósł się tylko do zgodności kwestionowanego przepisu z zasadą ochrony praw majątkowych (art. 64 ust. 1 Konstytucji RP), uzupełniając wzorzec kontroli o zasadę proporcjonalności (art. 31 ust. 3 Konstytucji RP). W odniesieniu do pozostałych wzorców konstytucyjnych wskazanych w pytaniu prawnym Trybunał uznał, że zachodzi niedopuszczalność wydania wyroku, gdyż sąd pytający nie przedstawił w tym zakresie odpowiedniego uzasadnienia, nie wskazał dostatecznych argumentów pozwalających na obalenie domniemania konstytucyjności kwestionowanej normy. W efekcie w tym zakresie postępowanie zostało umorzone. Nie kwestionując prawidłowości rozstrzygnięcia Trybunału w tym formalnym aspekcie, chciałbym odnieść się do pewnych wątków, które zostały przez to (zasadnie) pominięte, a zasługują na kilka uwag doktrynalnych.

\section{Konstytucyjne pojęcie wywłaszczenia a normatywne porządkowania stosunków własnościowych po podmiotach usuniętych $z$ rejestru}

Wśród wzorców kontroli konstytucyjności kwestionowanego art. 9 ust. 2b p.w.KRS sąd pytający wskazał art. 21 ust. 2 Konstytucji RP, zgodnie z którym wywłaszczenie jest dopuszczalne jedynie wówczas, gdy jest dokonywane na cele publiczne i za słusznym odszkodowaniem. W tym zakresie Trybunał nie udzielił odpowiedzi merytorycznej, uznając, że ten wzorzec konstytucyjny ,nie może stanowić podstawy merytorycznej kontroli zaskarżonej normy”, gdyż „nie obejmuje swym zakresem sytuacji, w związku 
z którą zainicjowane zostało [...] postępowanie [przed sądem odsyłającym]" (s. 11 uzasadnienia wyrokus).

Argumentację Trybunału trzeba moim zdaniem odnieść do szerszego zagadnienia zakresu przedmiotowego konstytucyjnego standardu wywłaszczenia.

Zakres konstytucyjnego pojęcia wywłaszczenia jest od dawna przedmiotem sporów doktrynalnych. $Z$ jednej strony prezentowane jest stanowisko, że pojęcie wywłaszczenia w konstytucji powinno być ujmowane wąsko, klasycznie, jako ograniczenie lub odjęcie w całości na cele publiczne prawa własności konkretnej nieruchomości na rzecz konkretnego podmiotu (Skarbu Państwa lub gminy), dokonywane w drodze aktu indywidualnego - decyzji administracyjnej ${ }^{6}$. $Z$ drugiej strony wyrażane są opinie, że konstytucyjny termin ,wywłaszczenie” powinien być interpretowany szeroko, w sposób niezależny od terminologii ustawodawstwa zwykłego. Zgodnie z tym stanowiskiem wywłaszczeniem jest wszelkie ograniczenie bądź pozbawienie przysługującego podmiotowi prawa majątkowego przez władzę publiczną?.

Poglądy Trybunału Konstytucyjnego w tej kwestii nie są jednolite — można znaleźć zarówno orzeczenia, w których skłaniano się ku wąskiemu, klasycznemu rozumieniu pojęcia wywłaszczenia zgodnie z przepisami Konstytucji $\mathrm{RP}^{8}$, jak i orzeczenia, w których Trybunał posługiwał się szerokim rozumieniem wywłaszczenia w ujęciu konstytucyjnego standardu ochrony własności ${ }^{9}$.

${ }^{5}$ Podaję numerację stron ze Zbioru Urzędowego OTK, w którym wyrok został opublikowany.

${ }^{6}$ Confer L. Garlicki, Polskie prawo konstytucyjne. Zarys wyktadu, Warszawa 2015, s. 115; M. Strzępek, Instytucja wywlaszczenia z art. 21 ust. 2 Konstytucji RP z 1997 r. w orzecznictwie Trybunału Konstytucyjnego, „Zeszyty Naukowe Sądownictwa Administracyjnego” 2012, nr 4, s. 98-99; K. Zaradkiewicz, komentarz do art. 21, [w:] Konstytucja RP, t. I: Komentarz. Art. 1-86, red. M. Safjan, L. Bosek, Warszawa 2016, s. 585.

7 Confer L. Bosek, Konstytucyjna formuła odpowiedzialności odszkodowawczej administracji publicznej, [w:] System Prawa Administracyjnego, t. 2: Konstytucyjne podstawy funkcjonowania administracji publicznej, red. R. Hauser, Z. Niewiadomski, A. Wróbel, Warszawa 2012, s. 575; T. Dybowski, Własność w przepisach konstytucyjnych wedle stanu obowiązującego w roku 1996, [w:] Konstytucja i gwarancje jej przestrzegania. Księga pamiatkowa ku czci prof. Janiny Zakrzewskiej, Warszawa 1996, s. 325; A. Hetko, Dekret warszawski. Wybrane aspekty systemowe, Warszawa 2012, s. 4; S. Jarosz-Żukowska, Konstytucyjna zasada ochrony własności, Kraków 2003, s. 233; P.T. Kociubiński, Powojenne przekształcenia własnościowe w świetle Konstytucji, Warszawa 2013, s. 120; C. Kosikowski, Zasada ochrony własności, [w:] Konstytucyjne podstawy systemu prawa, red. M. Wyrzykowski, Warszawa 2001, s. 237; M. Szalewska, Wywłaszczenie nieruchomości, Toruń 2005, s. 52; F. Zoll, Prawo własności w Europejskiej Konwencji Praw Czlowieka, „Przegląd Sądowy” 1998, nr 5, s. 31. Szerzej na temat argumentów w tej dyskusji vide J. Parchomiuk, Konstytucyjne podstawy odpowiedzialności odszkodowawczej z tytułu szkód wyrzadzonych zgodnym z prawem działaniem administracji publicznej, [w:] E. Bagińska, J. Parchomiuk, System Prawa Administracyjnego, t. 12: Odpowiedzialność odszkodowawcza w administracji, red. R. Hauser, Z. Niewiadomski, A. Wróbel, wyd. 2, Warszawa 2016, s. 160-168.

${ }^{8}$ Confer wyroki TK: z 28 maja 1991 r., sygn. akt K 1/91, OTK 1999, poz. 4; z 29 maja 2001 r., sygn. akt K 5/01, OTK 2001, nr 4, poz. 87; z 21 czerwca 2005 r., sygn. akt P 25/02, OTK-A 2005, nr 6, poz. 65; z 11 września 2006 r., sygn. akt P 14/06, OTK-A 2006, nr 8, poz. 102.

${ }^{9}$ Confer wyroki TK: z 8 maja 1990 r., sygn. akt K 1/90, OTK 1990, nr 2, poz. 7; z 14 marca 2000 r., sygn. akt P 5/99, OTK 2000, nr 2, poz. 60; z 24 października 2001 r., sygn. akt SK 22/01, OTK 2001, nr 7, poz. 216; z 28 stycznia 2003 r., sygn. akt K 2/02, OTK-A 2003, nr 1, poz. 4; z 21 czerwca 2005 r., sygn. akt P 25/02...; z 3 kwietnia 2008 r., sygn. akt K 6/05, OTK-A 2008, nr 3, poz. 411; z 13 grudnia 2012 r., sygn. akt P 12/11, OTK-A 2012, nr 11, poz. 135. 
Włączając się w tę dyskusję w swoich wcześniejszych publikacjach ${ }^{10}$, wyrażałem konsekwentnie i podtrzymuję pogląd o konieczności szerokiej interpretacji pojęcia wywłaszczenia w ramach Konstytucji, za czym przemawia przede wszystkim argument zapewnienia jak najpełniejszej ochrony praw jednostki przed ingerencjami ze strony władzy publicznej, jak również wzgląd na standard konwencyjny ochrony własności (szerokie rozumienie pojęcia wywłaszczenia zgodnie z Europejską Konwencją Praw Człowieka $\left.{ }^{11}\right)$.

Sposób rozumienia konstytucyjnego pojęcia wywłaszczenia (wąski lub szeroki) rodzi pytanie o to, jaki standard stosować do oceny tego rodzaju rozwiązań normatywnych, porządkujących stosunki własnościowe.

Pytanie prawne sądu odsyłającego opiera się na nader szerokim rozumieniu wywłaszczenia, obejmującym również przejęcie mienia przez podmiot publiczny bezpośrednio na podstawie przepisu ustawy. Tak szerokie rozumienie pojęcia wywłaszczenia stwarza istotny problem doktrynalny: w jaki sposób odgraniczyć tę instytucję od innych, zgodnych z prawem ingerencji władzy publicznej w prawo własności jednostki. Zbyt szeroka wykładnia konstytucyjnego terminu „wywłaszczenie” rodziłaby pokusę „podciągania” pod to pojęcie wszystkich przypadków ingerencji władzy publicznej w sferę prawa własności (rozumianego szeroko - obejmującego całokształt praw majątkowych). W konsekwencji za właściwy wzorzec kontroli w takich przypadkach należałoby uznawać m.in. właśnie art. 21 ust. 2 Konstytucji RP „z całym dobrodziejstwem inwentarza", tj. z koniecznością zapewnienia w każdym takim przypadku słusznego odszkodowania ${ }^{12}$.

Zagadnienie respektowania konstytucyjnych standardów ochrony własności w przypadku procesów normatywnego porządkowania stosunków własnościowych nie jest nowe. Przykładem chyba najbardziej doniosłym, biorąc pod uwagę zakres stosowania w praktyce, są regulacje dotyczące porządkowania statusu prawnego nieruchomości zajętych pod drogi publiczne na podstawie art. 73 ust. 1 ustawy z dnia 13 października 1998 r. - Przepisy wprowadzające ustawy reformujące administrację publiczną ${ }^{13}$. Zgodnie z tym przepisem nieruchomości pozostające $\mathrm{w}$ dniu 31 grudnia $1998 \mathrm{r}$. we władaniu Skarbu Państwa lub jednostek samorządu terytorialnego, niestanowiące ich własności, a zajęte pod drogi publiczne, z dniem 1 stycznia 1999 r. stają się z mocy prawa własnością Skarbu Państwa lub właściwych jednostek samorządu terytorialnego za odszkodowaniem. Przepis ten był już kilkukrotnie przedmiotem oceny ze strony TK, który nie dopatrzył się niezgodności z konstytucyjnymi i prawnomiędzynarodowymi regulacjami

10 J. Parchomiuk, Odpowiedzialność odszkodowawcza za legalne działania administracji publicznej, Warszawa 2007, s. 148-150; idem, Konstytucyjne podstawy odpowiedzialności..., s. 165-166.

${ }_{11}$ Zamiast wielu vide A. Wróbel, komentarz do art. 1 Protokołu dodatkowego nr 1 do Konwencji, [w:] Konwencja o Ochronie Praw Człowieka i Podstawowych Wolności, t. 2: Komentarz do artykułów 19-59 oraz protokołów dodatkowych, red. L. Garlicki, Warszawa 2011, s. 501-503, oraz J. Parchomiuk, Konstytucyjne podstawy odpowiedzialności..., s. 86-87.

12 Confer szerzej J. Parchomiuk, Odpowiedzialność odszkodowawcza..., s. 150-154.

13 Dz.U. nr 133, poz. 872, ze zm. [dalej: p.w.u.r.a.p.]. 
dotyczącymi ochrony własności ${ }^{14}$. Trybunał podkreślał jednak, że celem regulacji było uporządkowanie stosunków własnościowych z jednoczesnym ustanowieniem gwarancji zadośćuczynienia interesom właściciela, chodziło zatem o uregulowanie zastanych i powstałych w przeszłości stanów faktycznych. Ustawa dotyczy zatem tylko zaistniałych, nieodwracalnych sytuacji, nie zawiera natomiast regulacji, które mogłyby znaleźć zastosowanie w przyszłości do przejęcia nieruchomości z przeznaczeniem jej na drogę publiczną. Wobec tego z powyższej oceny zakwestionowanej regulacji nie można w żadnym razie wyciągać wniosków dla akceptacji analogicznych zabiegów faktycznych i prawodawczych w przyszłości ${ }^{15}$. Innymi słowy, rola tych przepisów właściwie zakończyła się, a w przypadkach nawet znacznego zapotrzebowania na prawa i dobra indywidualnych podmiotów w celu realizacji zadań publicznych muszą być wykorzystywane formy wywłaszczenia $\mathrm{w}$ drodze indywidualnego aktu podjętego na podstawie ustawy $^{16}$.

Co istotne dla prowadzonych tu wywodów, w trzech spośród czterech wyroków TK dotyczących art. 73 p.w.u.r.a.p. wzorcem kontroli był przede wszystkim właśnie art. 21 ust. 2 Konstytucji RP.

Argumentacja Trybunału zastosowana w komentowanym orzeczeniu opiera się na wywodzie, że kontrolowana regulacja nie stanowi wywłaszczenia w rozumieniu art. 21 ust. 2 Konstytucji RP, gdyż celem wprowadzonych regulacji było uporządkowanie wpisów w KRS, „doprowadzenie do stanu, w którym wpisy w KRS będą zgodne ze stanem rzeczywistym, by wzmocnić funkcje gwarancyjne tego rejestru" (s. 11 uzasadnienia). Wywód Trybunału można rozwinąć następująco: konstytucyjny standard wywłaszczenia (art. 21 ust. 2) ma zastosowanie wyłącznie do oceny takich ingerencji, których celem jest przejęcie własności prywatnej przez podmiot publiczny w związku z realizacją celu publicznego. Nie można standardu wywłaszczenia stosować w odniesieniu do takich ingerencji, które mają zupełnie inny cel, a przejęcie własności prywatnej przez podmiot publiczny jest jedynie swoistym wtórnym skutkiem. Nie oznacza to jednak pozbawienia podmiotów prywatnych konstytucyjnych gwarancji ochrony ich własności. Gwarancje

${ }^{14}$ Confer wyrok TK z 14 marca 2000 r. (sygn. akt P 5/99, OTK 2000, nr 2, poz. 60): ,Artykuł 73 ust. 1 i ust. 5 [p.w.u.r.a.p.] jest zgodny z art. 21 ust. 2 Konstytucji [RP] oraz z art. 1 Protokołu Nr 1 do Konwencji o Ochronie Praw Człowieka i Podstawowych Wolności [...] i nie jest niezgodny z art. 21 ust. 1 i art. 64 ust. 3 Konstytucji [RP]”; wyrok TK z 20 lipca 2004 r. (sygn. akt SK 11/02, OTK 2004, nr 7A, poz. 66): „Art. 73 ust. 4 [p.w.u.r.a.p.] jest zgodny z art. 21 ust. 2 Konstytucji [RP]”; wyrok TK z 15 września 2009 r. (sygn. akt P 33/07, OTK 2009, nr 8 A, poz. 123): „Art. 73 ust. 4 [p.w.u.r.a.p.] w zakresie, w jakim określa termin wygaśnięcia roszczenia o odszkodowanie bez powiązania z faktem i datą wydania decyzji, o której mowa w art. 73 ust. 3 tej ustawy, jest zgodny z art. 2, art. 32 ust. 1 i art. 64 ust. 2 Konstytucji [RP]”; wyrok z 19 maja 2011 r. (sygn. akt K 20/09, OTK 2011, nr 4A, poz. 35): „Art. 73 ust. 4 [p.w.u.r.a.p.] jest zgodny z art. 21 ust. 2 w zw. $\mathrm{z}$ art. 31 ust. 3 oraz z art. 2 Konstytucji [RP] i wywodzoną z niego zasadą poprawnej legislacji”.

${ }^{15}$ Confer zwłaszcza przywoływany wyżej wyrok TK z 14 marca 2000 r.

${ }^{16}$ Na epizodyczny charakter regulacji zwracano uwagę również w literaturze - confer J. Parchomiuk, Konstytucyjne podstawy odpowiedzialności..., s. 173; M. Zdyb, Konstytucyjne podstawy administracyjnoprawnych ograniczeń prawa własności jako podstawowego prawa rzeczowego (i ograniczonych praw rzeczowych), [w:] System Prawa Administracyjnego, t. 7: Prawo administracyjne materialne, red. R. Hauser, Z. Niewiadomski, A. Wróbel, Warszawa 2012, s. 594. 
te będą wynikały z innych standardów konstytucyjnych, w szczególności właśnie tych, które w analizowanej sprawie zastosował Trybunał — ochrony własności i innych praw majątkowych (art. 64 ust. 1 Konstytucji RP) oraz proporcjonalności władczej ingerencji (art. 31 ust. 3 Konstytucji RP).

W mojej ocenie argumentacja Trybunału może w tym zakresie budzić pewne wątpliwości. Rzeczywiście podstawowym celem regulacji zawartej w art. 9 p.w.KRS nie było wywłaszczenie, nawet szeroko rozumiane. Przede wszystkim chodziło o doprowadzenie do uporządkowania zapisów w rejestrach handlowych, usunięcia podmiotów „martwych” lub takich, których organy z różnych przyczyn nie były w stanie dopełnić przez wiele lat obowiązku przerejestrowania. Przedmiotem oceny Trybunału nie był jednak sam mechanizm wykreślania $\mathrm{z}$ rejestru, ale przepisy regulujące uporząakowanie stosunków majątkowych po podmiotach, które utraciły byt prawny w wyniku zastosowania tych mechanizmów. Analogia z orzeczeniami w sprawie art. 73 p.w.u.r.a.p. wydaje się dość oczywista — tam też chodziło o uporządkowanie stosunków własnościowych, o doprowadzenie do zgodności stanu prawnego nieruchomości ze stanem faktycznym, istniejącym często od wielu lat.

Moim zdaniem zawężenie wzorców kontroli i wykluczenie art. 21 ust. 2 Konstytucji RP lepiej oprzeć na nieco innych argumentach.

Jak wskazano wyżej, z uwagi na kluczową przesłankę związku funkcjonalnego pomiędzy pytaniem prawnym a rozstrzygnięciem sprawy zawisłej przed sądem Trybunał zasadnie zawęził zakres przedmiotu kontroli do normy wyrażonej w zd. 3 art. 9 ust. $2 b$ p.w.KRS. Gdyby zakres kontroli objął normę wyrażoną w zd. 1, prowadzącą do pozbawienia mienia samej spółki lub spółdzielni, w mojej ocenie konieczne byłoby wskazanie jako wzorca kontroli również art. 21 ust. 2 Konstytucji RP przy przyjęciu szerokiej interpretacji pojęcia wywłaszczenia.

Kontrolowana przez Trybunał norma prowadziła do utraty praw majątkowych (roszczeń) do partycypacji w majątku pozostałym po spółce czy spółdzielni wykreślonej z rejestru. Jak wskazano wyżej, szeroko rozumiane (zgodnie z art. 21 ust. 2 Konstytucji RP) wywłaszczenie obejmuje pozbawienie wszelkich praw majątkowych. Niemniej nawet przy szerokim rozumieniu do istoty wywłaszczenia należy transfer przedmiotu prawa majątkowego z podmiotu prywatnego na podmiot publiczny. $\mathrm{W}$ analizowanej normie (inaczej niż w zd. 1) nie widać elementu tego transferu - prowadzi ona do wygaśnięcia roszczeń przysługujących dawnym wspólnikom spółki lub członkom spółdzielni. Z tego względu bardziej jednoznacznym wzorcem kontroli wydaje się jednak art. 64 ust. 1 Konstytucji RP, statuujący ochronę szeroko pojmowanych praw majątkowych, bez wątpienia obejmujących również roszczenia do partycypacji w podziale składników majątku wykreślonej z rejestru spółki lub spółdzielni (vide trafne argumenty Trybunału co do charakteru tych roszczeń na s. 16-17 uzasadnienia wyroku).

Konkludując: wyłączenie z zakresu wzorców konstytucyjnych art. 21 ust. 2 Konstytucji RP uważam za prawidłowe, aczkolwiek moim zdaniem zabieg lepiej uzasadnić nieco innymi argumentami niż podniesione przez Trybunał. Co istotne, wyłączenie 
art. 21 ust. 2 Konstytucji RP jako wzorca kontroli nie miało negatywnych konsekwencji dla jednostki, gdyż ten sam standard ochrony konstytucyjnej Trybunał osiągnął dzięki zastosowaniu art. 64 ust. $1 \mathrm{w}$ zw. $\mathrm{z}$ art. 31 ust. 3 Konstytucji RP.

\section{Zasada ochrony własności oraz zasada proporcjonalności jako wzorzec oceny przepisów porządkujących stosunki własnościowe po podmiotach usuniętych $\mathrm{z}$ rejestru}

W perspektywie oceny kwestionowanych rozwiązań prawnych z punktu widzenia zasad ochrony własności i innych praw majątkowych (art. 64 ust. 1 Konstytucji RP) oraz zasady proporcjonalności (art. 31 ust. 3 Konstytucji RP) kluczowe są dwie konkluzje płynące z wywodów Trybunału.

Po pierwsze, Trybunał nie zakwestionował samego mechanizmu porządkowania stosunków własnościowych po podmiotach wykreślonych z rejestru wobec niedopełnienia obowiązku przerejestrowania do nowego KRS. Przyjęte rozwiązania w zakresie nieodpłatnego przejęcia mienia podmiotów, które zostały wykreślone z rejestru, oraz przejęcia odpowiedzialności z nabytego mienia za ich zobowiązania przez Skarb Państwa Trybunał uznał za środek konieczny z perspektywy zasady proporcjonalności. Jest to stwierdzenie kluczowe dla oceny skutków wyroku dla sporów związanych ze stosowaniem art. 9 ust. $2 \mathrm{~b}$ p.w.KRS rozstrzyganych na drodze administracyjnej i sądowoadministracyjnej, o czym będzie mowa w punkcie VI.

Stanowisko Trybunału zasługuje na pełną aprobatę. Biorąc pod uwagę motywy legislacyjne podawane przez ustawodawcę ${ }^{17}$, trzeba stwierdzić, że przyjęte przez prawodawcę rozwiązania stanowią wyraz dążenia do pogodzenia kolizji dwóch wartości chronionych Konstytucją: z jednej strony konieczności ochrony praw majątkowych byłych już członków lub udziałowców osób prawnych, które tracą byt prawny na skutek wykreślenia ex lege z rejestru; z drugiej — konieczności ochrony pewności obrotu i bezpieczeństwa prawnego. Nie do pogodzenia z tymi ostatnimi wartościami jest sytuacja, w której po podmiocie prawnym, którego byt prawny ustał, pozostało mienie o nieuregulowanym stanie prawnym, $w$ istocie niczyje. W takiej sytuacji ustawodawca

${ }^{17}$ Confer uzasadnienie projektu ustawy z dnia 28 listopada 2014 r. o zmianie ustawy o Krajowym Rejestrze Sądowym oraz niektórych innych ustaw (Sejm RP VII kadencji, druk sejmowy nr 2816), w szczególności rozdział zatytułowany „Wprowadzenie regulacji umożliwiającej sądowi rejestrowemu rozwiązanie i wykreślenie z rejestru tzw. martwych podmiotów". Jak wynika z motywów podanych przez projektodawcę, „proponowanego rozwiązania nie można uważać za zbyt drastyczne dla podmiotów, które — co do zasady — z dniem 1 stycznia $2016 \mathrm{r}$. przestaną istnieć, ponieważ okres ponad 13 lat — liczony od wejścia w życie ustawy o Krajowym Rejestrze Sądowym w dniu 1 stycznia 2001 r. - stwarzał dostateczne możliwości złożenia wniosku o wpis podmiotu do Krajowego Rejestru Sądowego przy zachowaniu minimum staranności ze strony zainteresowanych podmiotów". W dalszych wywodach wyjaśniono, że termin ten był już kilkakrotnie przedłużany. W ocenie projektodawcy ,[...] ze względu na pewność i bezpieczeństwo obrotu państwo nie może dłużej tolerować stanu, w którym wbrew obowiązującym regulacjom prawa krajowego i unijnego funkcjonują w obrocie podmioty nieprzerejestrowane do Krajowego Rejestru Sądowego". 
miał pełne podstawy do tego, aby przyjąć rozwiązania regulujące w sposób jednoznaczny zarówno status prawny podmiotów, które uległy wyrejestrowaniu ex lege, jak i status prawny mienia, do którego podmiotom tym przysługiwały prawa majątkowe. Przyjęte rozwiązania są w pełni racjonalnie uzasadnione koniecznością uporządkowania stosunków własnościowych po nieistniejącym podmiocie prawnym, zapobieżenia swoistej anarchii prawnej.

Po drugie, uznając potrzebę jednoznacznego uregulowania statusu prawnego mienia pozostałego po wykreślonych z rejestru podmiotach, Trybunał stwierdził, że rozwiązanie tego problemu przez ustawodawcę nie było w pełni prawidłowe, nie przeszło bowiem testu proporcjonalności w odniesieniu do roszczeń względem tego mienia przysługujących byłym wspólnikom spółek czy członkom spółdzielni. W ocenie Trybunału: „Z punktu widzenia założonego przez ustawodawcę celu za wystarczające należało uznać regulacje wprowadzone w art. 9 ust. $2 \mathrm{~b}$ zdanie pierwsze i drugie p.w.KRS. Doprowadzenie do przerejestrowania wszystkich podmiotów funkcjonujących w obrocie prawnym, a tym samym zagwarantowanie, że stan ujawniony w KRS będzie odpowiadał stanowi rzeczywistemu, nie wymagało pozbawienia wspólników ich praw majątkowych. Skutek w postaci utraty bytu prawnego spółek, które nie złożyły w przewidzianym czasie wniosku o przerejestrowanie, wraz z przejściem ich praw i obowiązków na następcę prawnego, jakim jest Skarb Państwa, spowodowało osiągnięcie zamierzonego przez ustawodawcę celu. Pozbawienie wspólników ich praw majątkowych wychodzi już poza granicę celowości wprowadzonych regulacji i z tego powodu jest zbędne" (s. 19-20 uzasadnienia).

Można wskazać argumenty przeciwne, broniące spornego rozwiązania. Przede wszystkim przez okres 15 lat (licząc od dnia wejścia w życie ustawy o KRS z 1997 r. — 1 stycznia 2001 r. — do dnia wejścia w życie spornych przepisów — 1 stycznia 2016 r.) istniała możliwość „przeniesienia” do nowego rejestru przedsiębiorców (obejmującego również spółdzielnie) podmiotów wpisanych do dotychczas prowadzonych rejestrów. Co więcej, przez pierwsze dwa lata (przy złożeniu wniosku do końca 2003 r.) przeniesienie następowało bez konieczności ponoszenia opłat rejestrowych. Gdyby natomiast nie było woli kontynuacji bytu prawnego danego podmiotu, należało przyjąć rozwiązania zapobiegające powstaniu stanu próżni prawnej, w którym istnieją składniki majątkowe, w szczególności nieruchomości o nieuregulowanym stanie prawnym. Taką możliwość bezpiecznego zakończenia bytu prawnego dawały procedury likwidacji spółki czy spółdzielni. Trzeba też mieć na uwadze fakt, że po podmiotach, które utraciły byt prawny w związku z wykreśleniem z rejestru, pozostały nie tylko aktywa (majątek), ale i pasywa (zobowiązania). Jeżeli utrata bytu prawnego nie następowała w procedurze likwidacyjnej, umożliwiającej zgłoszenia roszczeń przez wierzycieli, pojawiał się problem losów zobowiązań wykreślonego z rejestru podmiotu. Zgodnie z przyjętymi przez ustawodawcę rozwiązaniami Skarb Państwa nabywa nie tylko aktywa, ale i pasywa, ponosi bowiem odpowiedzialność z nabytego mienia za zobowiązania podmiotów, które utraciły byt prawny (art. 9 ust. $2 \mathrm{~b}$ p.w.KRS). Sporne rozwiązanie ustawowe oparto na swoistym mechanizmie ,grubej kreski”: Skarb Państwa przejmuje i majątek, i zobowiązania pozostałe po wykreślonym z rejestru podmiocie, jego wspólnicy (członkowie 
spółdzielni, inne osoby uprawnione) tracą jakiekolwiek roszczenia względem pozostałych składników majątkowych, choć jednocześnie nie ponoszą żadnej odpowiedzialności za zobowiązania wykreślonego $\mathrm{z}$ rejestru podmiotu.

Powyższe argumenty przywołuję po to, aby wskazać, że potencjalnie istniała droga argumentacji pozwalająca uznać, że sporne rozwiązania przechodzą test proporcjonalności. Nie krytykuję jednak stanowiska Trybunału — dokonał on wyboru pomiędzy dwiema drogami argumentacji i wybór ten szanuję. Nie sposób nie zgodzić się też z uwagą Trybunału, że trzeba uwzględnić fakt, iż obowiązek złożenia wniosku o przerejestrowanie spółki (spółdzielni) ciążył w efekcie na jej organach, za których działania i zaniechania nie ponoszą bezpośrednio odpowiedzialności wspólnicy (członkowie). „Dlatego też ustawodawca powinien odróżnić konsekwencje działania organów od konsekwencji, jakie w tym wypadku mogą odnosić się do wspólników spółki” (s. 21 uzasadnienia). Przejęcie przez Skarb Państwa zobowiązań wykreślonego z rejestru podmiotu nie oznacza, że kwestia tych obciążeń nie może być uwzględniona przy rozstrzyganiu o odszkodowaniu, jakiego może domagać się wspólnik (członek spółdzielni, inna osoba uprawniona) z tytułu partycypacji w składnikach pozostałego majątku wykreślonego z rejestru podmiotu. Obciążenia te powinny pomniejszać ewentualne odszkodowanie.

\section{Pozostałe wzorce oceny zgodności z Konstytucją RP art. 9 ust. 2 p.w.KRS}

W zakresie wskazanych przez sąd pytający wzorców kontroli w postaci art. 32 i art. 77 Konstytucji RP Trybunał nie zajął merytorycznego stanowiska. Nie kwestionuję prawidłowości formalnoprawnego rozstrzygnięcia Trybunału w tym zakresie. Nie dysponując argumentami Trybunału, można podnieść kilka uwag jedynie tytułem dodatkowego doktrynalnego komentarza.

W odniesieniu do zarzutu naruszenia zasady równości (art. 32 Konstytucji RP) Trybunał uznał, że sąd odsyłający nie przedstawił dostatecznych argumentów pozwalających obalić domniemanie zgodności konstytucyjności zakwestionowanego przepisu. „Sąd nie wskazał cechy relewantnej wyodrębnienia grup podmiotów pozwalającej na ocenę, czy rzeczywiście porównywane podmioty są podobne. Nie podniósł też argumentów uzasadniających zarzut arbitralności ustawodawcy w unormowaniu ich sytuacji” (s. 12 uzasadnienia). Analogiczne argumenty zadecydowały o tym, że Trybunał odrzucił dopuszczalność kontroli zgodności kwestionowanego przepisu z podobnym wzorcem konstytucyjnym — art. 64 ust. 3 — statuującym zasadę równej ochrony praw majątkowych.

Należy przypomnieć, że zasada równości wymaga równego traktowania podmiotów charakteryzujących się w takim samym stopniu cechą relewantną (istotną); innymi słowy — równego traktowania podmiotów znajdujących się w analogicznej sytuacji prawnej. Nie jest naruszeniem zasady równości odmienne traktowanie podmiotów, które 
znajdują się w odmiennej sytuacji prawnej i które nie charakteryzują się tą samą cechą istotną z punktu widzenia analizowanej regulacji prawnej ${ }^{18}$.

Argumentacja sądu odsyłającego opiera się na tym, że ustawodawca wprowadził różne mechanizmy przenoszenia wpisów ze „starych” rejestrów do nowego KRS, jak również odmienne od wynikających z art. 9 p.w.KRS zasady regulujące byt prawny mienia pozostałego po podmiocie wykreślonym $\mathrm{z}$ rejestru.

W mojej ocenie zarzut naruszenia zasady równości nie jest jednak uzasadniony. Trzeba mieć na uwadze fakt, że chodzi o odmienne sytuacje prawne niż ta, która jest podstawą sporu w rozpoznawanej sprawie.

Po pierwsze, zgodnie z art. 10 p.w.KRS podmioty podlegające obowiązkowi wpisu do rejestru stowarzyszeń, innych organizacji społecznych i zawodowych, fundacji oraz publicznych zakładów opieki zdrowotnej (w ramach nowo utworzonego KRS), wpisane do odpowiedniego rejestru przed dniem 1 stycznia $2001 \mathrm{r}$. wpisuje się do tego rejestru $\mathrm{z}$ urzędu. Trudno jednak nie dostrzec odmienności podmiotowej uzasadniającej odmienne traktowanie: spółki czy spółdzielnie, których dotyczy art. 9 p.w.KRS, są przedsiębiorstwami. Nie jest moim zdaniem nierównym traktowaniem wymaganie od podmiotu uczestniczącego w obrocie gospodarczym, aby dochował wymaganej od profesjonalisty staranności i dopełnił obowiązku przerejestrowania do nowego rejestru (zwłaszcza biorąc pod uwagę tak długi okres). Ponadto przeniesienie z urzędu wszystkich wpisów przedsiębiorców ze starych rejestrów do nowego rejestru w KRS godziłoby w wartość bezpieczeństwa prawnego, prowadziłoby bowiem do zachowania wpisów podmiotów „martwych”, od dawna nieprowadzących żadnej aktywności w obrocie gospodarczym. Właśnie wymóg złożenia stosownego wniosku o przerejestrowanie zachęcał do wykazania aktywności przez podmiot, który miał zostać przeniesiony do nowego rejestru.

Po drugie, ta sama wspomniana wyżej ustawa nowelizująca z dnia 28 listopada 2014 r. wprowadziła do ustawy o Krajowym Rejestrze Sądowym art. 25e, zgodnie z którym Skarb Państwa nabywa nieodpłatnie z mocy prawa pozostałe po wykreślonym z rejestru podmiocie (bez względu na przyczynę wykreślenia) mienie, którym nie rozporządził przed wykreśleniem właściwy organ, z chwilą wykreślenia z rejestru (ust. 1). Skarb Państwa ponosi odpowiedzialność z nabytego mienia za zobowiązania podmiotu wykreślonego z rejestru (ust. 2). Wspólnicy, członkowie spółdzielni i inne osoby uprawnione do udziału w majątku likwidacyjnym mogą dochodzić swoich praw, gdy reprezentują łącznie co najmniej dwie trzecie głosów i wykażą, że wszyscy wierzyciele zostali zaspokojeni lub zabezpieczeni, jednakże roszczenia ta wygasają, jeżeli nie będą dochodzone przeciwko Skarbowi Państwa w terminie roku od chwili nabycia mienia przez Skarb Państwa (ust. 3 i 4).

18 Spośród nader bogatego orzecznictwa Trybunału Konstytucyjnego confer przykładowo: orzeczenia z 9 marca 1988 r., sygn. akt U 7/87, OTK 1988, t. I, poz. 1; z 4 lutego 1997 r., sygn. akt P 4/96, OTK 1997, nr 1, poz. 3; z 9 czerwca 1997 r., sygn. akt K 24/96, OTK 1997, nr 2, poz. 20 . Z literatury przedmiotu zamiast wielu vide W. Borysiak, L. Bosek, komentarz do art. 32, [w:] Konstytucja RP, t. 1: Komentarz. Art. 1-86, red. M. Safjan, L. Bosek, Warszawa 2016, s. 831 oraz przywoływane tam literatura i orzecznictwo. 
W mojej ocenie, wbrew argumentom sądu pytającego, odmienne regulacje (z jednej strony art. 9 p.w.KRS, z drugiej — art. 25e ustawy o KRS) nie prowadzą do naruszenia zasady równości wobec prawa. Pierwszy przepis odnosi się do podmiotu, który pozostał bierny pomimo obowiązku złożenia stosownego wniosku o przerejestrowanie do nowego rejestru przedsiębiorców, oraz do majątku pozostałego po tym podmiocie, w sensie prawnym niczyjego. Drugi zaś przepis służy uregulowaniu sytuacji, gdy po przeprowadzeniu likwidacji podmiot zostanie wykreślony z Krajowego Rejestru Sądowego, a po jego wykreśleniu (tj. po utracie bytu prawnego) ujawni się majątek tego podmiotu, który nie został objęty likwidacją ${ }^{19}$. Nie są to zatem sytuacje tożsame - istnieje między nimi kluczowa różnica sprawiająca, że brak jest wspomnianej cechy relewantnej. To zaś wyklucza zasadne podnoszenie zarzutu nierównego traktowania.

Duże wątpliwości budzi wskazanie art. 77 Konstytucji RP jako wzorca konstytucyjności. Przede wszystkim jest to regulacja nader złożona, dotyczy bowiem dwóch wprawdzie powiązanych, ale jednak odrębnych kwestii. W ust. 1 zostało wyrażone konstytucyjne prawo podmiotowe do naprawienia szkody wyrządzonej niezgodnym z prawem działaniem organu władzy publicznej. W ust. 2 ustrojodawca wyraził natomiast zakaz zamykania drogi sądowej dochodzenia naruszonych wolności i praw. Ocena zastosowania tego przepisu jako wzorca kontroli konstytucyjności musi opierać się na różnych argumentach.

Analizując art. 77 ust. 1 Konstytucji RP jako potencjalny wzorzec kontroli art. 9 ust. $2 b$ p.w.KRS, trzeba zauważyć, że przepis ten nakłada obowiązek zapewnienia odszkodowania za szkodę wyrządzoną władczym bezprawiem, nie odnosi się zaś do szkód wyrządzonych zgodnym z prawem aktem organu władzy publicznej (nie wyłączając aktu normatywnego). W Konstytucji RP nie ma odpowiednika art. 77 ust. 1, który stanowiłby ogólną podstawę prawa podmiotowego do odszkodowania za tzw. szkody legalne. De lege lata nie można zatem konstruować w polskim porządku prawnym publicznego prawa podmiotowego do odszkodowania z tytułu szkód wyrządzonych zgodnym z prawem działaniem władzy publicznej in genere, tzn. takiego, z którego wynikałaby możliwość podniesienia roszczeń odszkodowawczych w każdym przypadku władczej ingerencji. Można jedynie mówić o prawie podmiotowym do odszkodowania w poszczególnych przypadkach ingerencji (np. wywłaszczenia, ograniczeń w korzystaniu z własności nieruchomości, ograniczenia w czasie stanów nadzwyczajnych wolności i praw człowieka, wyrządzenia szkody na osobie) ${ }^{20}$. Skoro, jak wywiedziono wyżej, sama regulacja powodująca przejęcie przez Skarb Państwa mienia podmiotów wykreślonych $\mathrm{z}$ rejestru, w celu uporządkowania stosunków własnościowych, nie narusza standardów konstytucyjnych, art. 77 ust. 1 Konstytucji RP nie jest właściwym wzorcem kontroli, co słusznie zauważył Trybunał w komentowanym wyroku. Art. 77 ust. 1 Konstytucji RP ma natomiast zupełnie inne znaczenie w analizowanej sytuacji: skoro pozbawienie byłych wspólników (członków spółdzielni, innych uprawnionych) prawa

\footnotetext{
19 Vide uzasadnienie ww. projektu ustawy z dnia 28 listopada 2014 r. o zmianie..., pkt 4.2.

${ }^{20}$ Confer szerzej J. Parchomiuk, Odpowiedzialność odszkodowawcza..., s. 190 i n.
} 
do partycypowania w składnikach majątku pozostałego po wykreślonym z rejestru podmiocie było niezgodne z konstytucją, analizowany przepis daje tym podmiotom podstawę prawną (w zw. z art. $417^{1} \S 1$ k.c.) dochodzenia roszczeń odszkodowawczych z tytułu bezprawia legislacyjnego.

W argumentacji Trybunału pojawia się natomiast pewna niezręczność — chodzi o stwierdzenie, że art. 77 ust. 1 Konstytucji RP ,nie stanowi odrębnej (samoistnej) podstawy kontroli konstytucyjności ustaw" (vide s. 13 uzasadnienia). Niezręczność wynika z faktu, że wręcz przeciwnie, Trybunał wydał do tej pory już kilka orzeczeń, w których art. 77 ust. 1 stanowił wzorzec kontroli konstytucyjnej, choć rzeczywiście - często $\mathrm{w}$ powiązaniu $\mathrm{z}$ innymi wzorcami ${ }^{21}$. Natomiast sama ocena co do istoty problemu jest jak najbardziej trafna.

W odniesieniu do art. 77 ust. 2 Konstytucji RP jako wzorca kontroli art. 9 ust. 2b p.w.KRS również w pełni zgadzam się ze stanowiskiem Trybunału odrzucającego ten pogląd. Trudno wykazać, w jaki sposób kwestionowany przepis miałby zamykać drogę dochodzenia roszczeń. Istota problemu leży nie tyle w zamknięciu drogi dochodzenia roszczeń, bo w tym zakresie droga sądowa jest potencjalnie otwarta, ile w naruszeniu zasad ochrony własności i proporcjonalności przez pozbawienie odszkodowania. W związku z tym art. 77 ust. 2 Konstytucji RP nie jest tu odpowiednim wzorcem kontroli.

\section{Skutki wyroku}

Zasadniczo nie mam zastrzeżeń co do wywodów Trybunału dotyczących skutków komentowanego wyroku. Jak wskazano wyżej, skoro pozbawienie byłych wspólników (członków spółdzielni, innych uprawnionych) prawa do partycypowania w składnikach majątku pozostałego po wykreślonym z rejestru podmiocie było niezgodne z konstytucją, podmioty te mają prawo dochodzenia roszczeń odszkodowawczych z tytułu bezprawia legislacyjnego na podstawie art. 77 ust. 1 Konstytucji RP i art. $417^{1} \S 1$ k.c. Uzupełniając argumentację Trybunału, należy zauważyć, że skoro uznano za zgodny ze standardem konstytucyjnym sam mechanizm porządkowania stosunków własnościowych, nie ma możliwości skorzystania z tzw. pierwotnych środków ochrony praw i wolności (niem. Primärrechtschutzgarantie), które są ukierunkowane na zapobieganie naruszeniom lub bezpośrednie odwrócenie ich skutków. Przywrócenie standardu

${ }^{21}$ Art. 77 ust. 1 jako samodzielny wzorzec oceny - confer wyroki TK: z 4 grudnia 2001 r., sygn. akt SK 18/00, OTK 2001, nr 8, poz. 256; z 23 września 2003 r., sygn. akt K 20/02, OTK-A 2003, nr 7, poz. 76; z 20 stycznia 2004 r., sygn. akt SK 26/03, OTK-A 2004, nr 1, poz. 3; z 1 września 2006 r., sygn. akt SK 14/05, OTK-A 2006, nr 8, poz. 97; z 11 września 2006 r., sygn. akt P 14/06..; z 27 września 2012 r., sygn. akt SK 4/11, OTK-A 2012, nr 8, poz. 97. W powiązaniu z innymi wzorcami - confer wyroki TK: z 3 marca 2004 r., sygn. akt K 29/03, OTK-A 2004, nr 3, poz. 17; z 23 maja 2006 r., sygn. akt SK 51/05, OTK-A 2006, nr 5, poz. 58; z 1 kwietnia 2008 r., sygn. akt SK 77/06, OTK-A 2008, nr 3, poz. 39; z 21 lipca 2010 r., sygn. akt SK 21/08, OTK-A 2010, nr 6, poz. 62; z 6 listopada 2012 r., sygn. akt SK 29/11, OTK-A 2012, nr 10, poz. 120; z 27 października 2015 r., sygn. akt SK 9/13, OTK-A 2015, nr 9, poz. 151. 
konstytucyjności nastąpi wyłącznie poprzez zastosowanie wtórnych środków ochrony (niem. Sekundärechtschutzgarantie) poprzez roszczenia odszkodowawcze ${ }^{22}$.

W rozważaniach Trybunału nie pojawił się natomiast inny aspekt skutków wyroku Trybunału — w odniesieniu do sporów rozpatrywanych na drodze administracyjnej i sądowoadministracyjnej. Jak wskazano wyżej, mienie podmiotów wykreślonych z rejestru nabył z mocy prawa Skarb Państwa, ale skutek ten stwierdza w drodze decyzji (mającej charakter deklaratoryjny) starosta właściwy ze względu na miejsce położenia nieruchomości (art. 9 ust. 2 i zd. 1 p.w.KRS). Decyzje te po wyczerpaniu administracyjnego toku instancji mogły być przedmiotem skarg do sądu administracyjnego ${ }^{23}$.

Pojawia się zatem pytanie o skutki analizowanego wyroku dla spraw dotyczących stwierdzenia nabycia mienia przez Skarb Państwa zawisłych przez organami lub sądami, jak również dla spraw zakończonych ostateczną decyzją lub prawomocnym orzeczeniem sądu administracyjnego. W tym drugim przypadku trzeba przypomnieć, że orzeczenie Trybunału Konstytucyjnego o niezgodności aktu normatywnego z konstytucją, umową międzynarodową lub z ustawą, na podstawie którego została wydana decyzja ostateczna lub prawomocne orzeczenie sądu administracyjnego, stanowi podstawę do wznowienia odpowiednio postępowania administracyjnego (art. 145a § 1 Kodeksu postępowania administracyjnego) lub sądowoadministracyjnego (art. $272 \S 1$ ustawy Prawo o postępowaniu przed sądami administracyjnymi).

W mojej ocenie, biorąc pod uwagę treść rozstrzygnięcia Trybunału, komentowany wyrok nie wpływa ani na treść decyzji o stwierdzeniu nabycia mienia przez Skarb Państwa, jakie mają być wydane w sprawach jeszcze zawisłych przed organami, ani na ocenę legalności tych decyzji przez sądy administracyjne, nie stanowi również podstawy do wznowienia postępowania administracyjnego lub sądowoadministracyjnego.

Przesądza o tym zakres rozstrzygnięcia Trybunału: jeszcze raz należy podkreślić, że Trybunał stwierdził niekonstytucyjność wyłącznie normy wygaszającej prawa wspólników, członków spółdzielni i innych osób uprawnionych do udziału w majątku likwidacyjnym podmiotów wykreślonych z rejestru (art. $9 b$ ust. 2 zd. 3 p.w.KRS). Orzeczenie Trybunału nie dotyczy tej normy, która stanowiła podstawę wydania decyzji deklaratoryjnej starosty stwierdzającej nieodpłatne nabycie mienia przez Skarb Państwa (zdanie pierwsze przywoływanego przepisu). Co więcej, jak wskazano wyżej, Trybunał nie zakwestionował samego mechanizmu porządkowania stosunków własnościowych po podmiotach wykreślonych z rejestru wobec niedopełnienia obowiązku przerejestrowania do

${ }^{22}$ Odwołuję się w tym miejscu do koncepcji niemieckich odpowiedzialności odszkodowawczej państwa jako środka wtórnej ochrony praw i wolności jednostki. Confer S. Detterbeck, K. Windthorst, H.-D. Sproll, Staatshaftungsrecht, München 2000, s. 1; H. Maurer, Allgemeines Verwaltungsrecht, München 1994, s. 586; H. Bethge, Die Grundlagen des Staatshaftungsrecht der Bundesrepublik Deutschland, [w:] Entwicklungen im Staatshaftungsrecht, red. F.O. Kopp, Passau 1982, s. 16-17.

${ }^{23}$ Confer przykładowo: wyrok WSA w Kielcach z 1 marca 2018 r., sygn. akt II SA/Ke 43/18; wyroki WSA w Poznaniu z 18 października 2017 r., sygn. akt II SA/Po 463/17, i z 19 czerwca 2018 r., sygn. akt II SA/Po 90/18; wyrok WSA we Wrocławiu z 13 czerwca 2018 r., sygn. akt II SA/Wr 792/17; wyrok WSA w Lublinie z 7 lutego 2019 r., sygn. akt II SA/Lu 946/18; wyrok WSA w Lodzi z 18 września 2019 r., sygn. akt II SA/Łd 372/19; wyrok WSA w Gdańsku z 9 stycznia 2020 r., sygn. akt II SA/Gd 354/19. 
nowego KRS. W związku z tym wyrok Trybunału nie ma żadnego wpływu na decyzje deklaratoryjne wydawane przez starostów na podstawie art. 9 ust. $2 \mathrm{i}$ zd. 1 p.w.KRS. Dotyczy to również wznowienia postępowania. Po pierwsze, uznany za niekonstytucyjny przepis - art. 9 b ust. 2 zd. 3 p.w.KRS - nie stanowił ani podstawy decyzji starosty, ani orzeczenia sądu administracyjnego kontrolującego legalność tej decyzji. Po drugie, wznowienie postępowania (zarówno administracyjnego, jak i sądowoadministracyjnego) z założenia ma doprowadzić do ponownego rozpatrzenia sprawy z pominięciem normy uznanej za niekonstytucyjną. Ponowne rozpatrzenie sprawy z pominięciem uznanego za niezgodny z konstytucją art. 9 ust. 2b zd. 3 p.w.KRS nie wpłynęłoby w żaden sposób na treść decyzji ani orzeczenia sądu administracyjnego.

Oceny tej nie zmienia jeszcze jedna kwestia — w niektórych sprawach organy przyjmowały, że ze względu na wygaśnięcie praw wspólnicy (członkowie spółdzielni) nie mają interesu prawnego, nie mogą być zatem stronami postępowania w sprawie decyzji starosty wydawanej na podstawie art. 9 ust. $2 \mathrm{i}$ zd. 1 p.w.KRS ${ }^{24}$. W mojej opinii wyrok Trybunału nie daje podstaw do wznowienia postępowań, w których rozstrzygnięcia były oparte na takiej argumentacji. Z orzeczenia Trybunału jasno wynika, że właściwą drogą ochrony interesów prawnych tych podmiotów są roszczenia odszkodowawcze z tytułu bezprawia legislacyjnego, dochodzone w postępowaniach przed sądami powszechnymi (w postępowaniu cywilnym). Cały ciężar przywrócenia stanu zgodnego ze standardami konstytucyjnymi został przeniesiony na spory odszkodowawcze.

\section{Podsumowanie}

Podsumowując powyższe rozważania szczegółowe, w pełni akceptuję stanowisko Trybunału co do istoty rozstrzygnięcia, choć dostrzegam też możliwość uzasadnienia stanowiska przeciwnego. Zgadzam się również zasadniczo z argumentacją podaną w uzasadnieniu, choć co do niektórych kwestii (w szczególności ograniczenia zakresu wzorców konstytucyjnych) użyłbym nieco innej argumentacji.

W zakresie konsekwencji analizowanego wyroku w mojej ocenie na szczególne podkreślenie zasługuje fakt, że Trybunał nie zakwestionował samego mechanizmu porządkowania stosunków własnościowych po podmiotach wykreślonych z rejestru wobec niedopełnienia obowiązku przerejestrowania do nowego KRS. W konsekwencji wyrok Trybunału nie wpłynie na rozstrzyganie spraw dotyczących stwierdzenia nabycia przez Skarb Państwa mienia pozostałego po podmiotach wykreślonych z rejestru ani w aspekcie treści decyzji administracyjnych w tym przedmiocie, ani oceny legalności tych decyzji przez sądy administracyjne, nie będzie również stanowił podstawy do wznowienia

${ }^{24}$ Confer przykładowo: wyrok WSA w Lublinie z 15 lutego 2018 r. (sygn. akt II SA/Lu 1005/17) uchylający oparte na takiej argumentacji postanowienie stwierdzające niedopuszczalność odwołania wniesionego przez byłych członków spółdzielni. Odmienny pogląd, wykluczający przyznanie byłym członkom spółdzielni statusu stron postępowania w sprawie stwierdzenia nabycia mienia przez Skarb Państwa wyraził WSA w Gdańsku w wyroku z 9 stycznia 2020 r., sygn. akt II SA/Gd 588/19. 
postępowań administracyjnych lub sądowoadministracyjnych w sprawach, w których wydano już ostateczne decyzje lub prawomocne wyroki.

Niekonstytucyjne okazały się wyłącznie rozwiązania wygaszające roszczenia względem tego mienia przysługujące byłym wspólnikom spółek czy członkom spółdzielni. Cały ciężar przywrócenia standardu konstytucyjnego ochrony praw majątkowych zostanie jednak przesunięty na spory cywilne o odszkodowanie względem Skarbu Państwa z tytułu bezprawia legislacyjnego wyrażającego się w bezprawnym (niekonstytucyjnym) pozbawieniu praw majątkowych byłych wspólników wykreślonych z rejestru spółek czy byłych członków wykreślonych z rejestru spółdzielni.

Jerzy Parchomiuk*

* Dr hab. Jerzy Parchomiuk, Katolicki Uniwersytet Lubelski Jana Pawła II, Wydział Prawa, Prawa Kanonicznego i Administracji, Katedra Prawa Administracyjnego, jerzy.parchomiuk@kul.lublin.pl,https://orcid.org/0000-0001-9252-6963

\section{Bibliografia}

\section{ŹRÓDŁA}

Orzeczenie TK z 9 marca 1988 r., sygn. akt U 7/87, OTK 1988, t. I, poz. 1.

Orzeczenie TK z 8 maja 1990 r., sygn. akt K 1/90, OTK 1990, nr 2, poz. 7.

Orzeczenie TK z 28 maja 1991 r., sygn. akt K 1/91, OTK 1999, poz. 4.

Orzeczenie TK z 4 lutego 1997 r., sygn. akt P 4/96, OTK 1997, nr 1, poz. 3.

Orzeczenie TK z 9 czerwca 1997 r., sygn. akt K 24/96, OTK 1997, nr 2, poz. 20.

Ustawa z dnia 20 sierpnia 1997 r. - Przepisy wprowadzające ustawę o Krajowym Rejestrze Sądowym, Dz.U. z 1997 r. nr 121, poz. 770, ze zm.

Ustawa z dnia 13 października 1998 r. - Przepisy wprowadzające ustawy reformujące administrację publiczną, Dz.U. nr 133, poz. 872, ze zm.

Ustawa z dnia 28 listopada 2014 r. o zmianie ustawy o Krajowym Rejestrze Sądowym oraz niektórych innych ustaw, Dz.U. z 2014 r. poz. 1924.

Ustawa z dnia 30 listopada 2016 r. o organizacji i trybie postępowania przed Trybunałem Konstytucyjnym, Dz.U. z 2016 r. poz. 2072, ze zm.

Uzasadnienie projektu ustawy z dnia 28 listopada 2014 r. o zmianie ustawy o Krajowym Rejestrze Sądowym oraz niektórych innych ustaw, Sejm RP VII kadencji, druk sejmowy nr 2816.

Wyrok TK z 14 marca 2000 r., sygn. akt P 5/99, OTK 2000, nr 2, poz. 60.

Wyrok TK z 29 maja 2001 r., sygn. akt K 5/01, OTK 2001, nr 4, poz. 87.

Wyrok TK z 24 października 2001 r., sygn. akt SK 22/01, OTK 2001, nr 7, poz. 216.

Wyrok TK z 4 grudnia 2001 r., sygn. akt SK 18/00, OTK 2001, nr 8, poz. 256.

Wyrok TK z 28 stycznia 2003 r., sygn. akt K 2/02, OTK-A 2003, nr 1, poz. 4.

Wyrok TK z 23 września 2003 r., sygn. akt K 20/02, OTK-A 2003, nr 7, poz. 76.

Wyrok TK z 20 stycznia 2004 r., sygn. akt SK 26/03, OTK-A 2004, nr 1, poz. 3.

Wyrok TK z 3 marca 2004 r., sygn. akt K 29/03, OTK-A 2004, nr 3, poz. 17.

Wyrok TK z 20 lipca 2004 r., sygn. akt SK 11/02, OTK 2004, nr 7A, poz. 66. 
Wyrok TK z 21 czerwca 2005 r., sygn. akt P 25/02, OTK-A 2005, nr 6, poz. 65. Wyrok TK z 23 maja 2006 r., sygn. akt SK 51/05, OTK-A 2006, nr 5, poz. 58. Wyrok TK z 1 września 2006 r., sygn. akt SK 14/05, OTK-A 2006, nr 8, poz. 97. Wyrok TK z 11 września 2006 r., sygn. akt P 14/06, OTK-A 2006, nr 8, poz. 102. Wyrok TK z 1 kwietnia 2008 r., sygn. akt SK 77/06, OTK-A 2008, nr 3, poz. 39. Wyrok TK z 3 kwietnia 2008 r., sygn. akt K 6/05, OTK-A 2008, nr 3, poz. 411. Wyrok TK z 15 września 2009 r., sygn. akt P 33/07, OTK 2009, nr 8A, poz. 123. Wyrok TK z 21 lipca 2010 r., sygn. akt SK 21/08, OTK-A 2010, nr 6, poz. 62. Wyrok TK z 19 maja 2011 r., sygn. akt K 20/09, OTK 2011, nr 4A, poz. 35. Wyrok TK z 27 września 2012 r., sygn. akt SK 4/11, OTK-A 2012, nr 8, poz. 97. Wyrok TK z 6 listopada 2012 r., sygn. akt SK 29/11, OTK-A 2012, nr 10, poz. 120. Wyrok TK z 13 grudnia 2012 r., sygn. akt P 12/11, OTK-A 2012, nr 11, poz. 135. Wyrok TK z 27 października 2015 r., sygn. akt SK 9/13, OTK-A 2015, nr 9, poz. 151. Wyrok TK z 11 grudnia 2019 r., sygn. akt P 13/19, OTK-A 2019, poz. 68. Wyrok WSA w Gdańsku z 9 stycznia 2020 r., sygn. akt II SA/Gd 354/19. Wyrok WSA w Gdańsku z 9 stycznia 2020 r., sygn. akt II SA/Gd 588/19. Wyrok WSA w Kielcach z 1 marca 2018 r., sygn. akt II SA/Ke 43/18. Wyrok WSA w Lublinie z 15 lutego 2018 r., sygn. akt II SA/Lu 1005/17. Wyrok WSA w Lublinie z 7 lutego 2019 r., sygn. akt II SA/Lu 946/18. Wyrok WSA w Łodzi z 18 września 2019 r., sygn. akt II SA/Łd 372/19. Wyrok WSA w Poznaniu z 18 października 2017 r., sygn. akt II SA/Po 463/17. Wyrok WSA w Poznaniu z 19 czerwca 2018 r., sygn. akt II SA/Po 90/18. Wyrok WSA we Wrocławiu z 13 czerwca 2018 r., sygn. akt II SA/Wr 792/17.

\section{PIŚMIENNICTWO}

Bethge H., Die Grundlagen des Staatshaftungsrecht der Bundesrepublik Deutschland, [w:] Entwicklungen im Staatshaftungsrecht, red. F.O. Kopp, Schriften der Universität Passau, Band I, Passau 1982.

Bosek L., Konstytucyjna formuła odpowiedzialności odszkodowawczej administracji publicznej, [w:] System Prawa Administracyjnego, t. 2: Konstytucyjne podstawy funkcjonowania administracji publicznej, red. R. Hauser, Z. Niewiadomski, A. Wróbel, C.H.Beck, Instytut Nauk Prawnych PAN, Warszawa 2012.

Detterbeck S., Windthorst K., Sproll H.-D., Staatshaftungsrecht, C.H.Beck, München 2000.

Dybowski T., Własność w przepisach konstytucyjnych wedle stanu obowiazujacego w roku 1996,

[w:] Konstytucja i gwarancje jej przestrzegania. Księga pamiątkowa ku czci prof. Janiny Zakrzewskiej, Biuro Trybunału Konstytucyjnego, Warszawa 1996.

Garlicki L., Polskie prawo konstytucyjne. Zarys wyktadu, Liber, Warszawa 2015.

Hetko A., Dekret warszawski. Wybrane aspekty systemowe, C.H.Beck, Warszawa 2012.

Jarosz-Żukowska S., Konstytucyjna zasada ochrony własności, Zakamycze, Kraków 2003.

Kociubiński P.T., Powojenne przekształcenia wtasnościowe w świetle Konstytucji, LEX a Wolters Kluwer business, Warszawa 2013.

Konstytucja RP, t. 1: Komentarz. Art. 1-86, red. M. Safjan, L. Bosek, C.H.Beck, Warszawa 2016.

Konwencja o Ochronie Praw Człowieka i Podstawowych Wolności, t. 2: Komentarz do artykułów 19-59 oraz protokołów dodatkowych, red. L. Garlicki, C.H.Beck, Warszawa 2011.

Kosikowski C., Zasada ochrony własności, [w:] Konstytucyjne podstawy systemu prawa, red. M. Wyrzykowski, Instytut Spraw Publicznych, Warszawa 2001.

Maurer H., Allgemeines Verwaltungsrecht, C.H.Beck, München 1994. 
Parchomiuk J., Konstytucyjne podstawy odpowiedzialności odszkodowawczej z tytułu szkód wyrzadzonych zgodnym z prawem działaniem administracji publicznej, [w:] E. Bagińska, J. Parchomiuk, System Prawa Administracyjnego, t. 12: Odpowiedzialność odszkodowa$w c z a$ w administracji, red. R. Hauser, Z. Niewiadomski, A. Wróbel, wyd. 2, C.H.Beck, Instytut Nauk Prawnych PAN, Warszawa 2016.

Parchomiuk J., Odpowiedzialność odszkodowawcza za legalne działania administracji publicznej, C.H.Beck, Warszawa 2007.

Strzępek M., Instytucja wywłaszczenia z art. 21 ust. 2 Konstytucji RP z 1997 r. w orzecznictwie Trybunału Konstytucyjnego, „Zeszyty Naukowe Sądownictwa Administracyjnego” 2012, nr 4.

Szalewska M., Wywłaszczenie nieruchomości, TNOiK „Dom Organizatora”, Toruń 2005.

Zdyb M., Konstytucyjne podstawy administracyjnoprawnych ograniczeń prawa własności jako podstawowego prawa rzeczowego (i ograniczonych praw rzeczowych), [w:] System Prawa Administracyjnego, t. 7: Prawo administracyjne materialne, red. R. Hauser, Z. Niewiadomski, A. Wróbel, C.H.Beck, Instytut Nauk Prawnych PAN, Warszawa 2012.

Zoll F., Prawo własności w Europejskiej Konwencji Praw Człowieka, „Przegląd Sądowy” 1998, nr 5. 